DOI: $10.1515 / \mathrm{rpp}-2016-0005$

$\mathrm{PhD}$ in Pedagogical Sciences, Associate Professor, VICTORIA PAVLYUK

Pavlo Tychyna Uman State Pedagogical University, Ukraine Address: 2 Sadova St., Cherkasy Region, Uman, 20300, Ukraine

E-mail: vika.pavlyuk.83@mail.ru

PhD in Pedagogical Sciences, Associate Professor, HALYNA IVANCHYUK

Pavlo Tychyna Uman State Pedagogical University, Ukraine Address: 2 Sadova St., Cherkasy Region, Uman, 20300, Ukraine E-mail: ivanchck@meta.ua

\title{
PECULIARITIES IN CONSTRUCTION \\ OF FUTURE TEACHERS' PROFESSIONAL TRAINING CONTENT IN THE SYSTEM OF MULTILEVEL PEDAGOGICAL EDUCATION IN CANADA
}

\section{ABSTRACT}

The article deals with the peculiarities of future teachers' training content in the system of Canadian multilevel teacher education. Main features of the Canadian teachers' training content are the standardization of multilevel pedagogical education content, Canada's focus on multilevel teachers' education in professional development of future teachers, establishing optimal scientific balance between disciplines of different cycles, theoretical and practical units (modules), interdisciplinary guidelines for Canadian teachers. Teaching methods oriented at obtaining professional training by future teachers in Canada, including selected methods of preparation for practical activities and methods of creative thinking, have been emphasized. Based on research and analysis of referenceencyclopedic sources it has been found out that changes in Canadian society in the late 19th-21st centuries led to new demands and duties of teachers set out in the standards of their professional evaluation. It has been determined that the development of the Canadian system of teacher education in terms of multilevelness is targeted at training future teachers competitive in the labour market.

Key words: future teachers' training, the system of multilevel teacher education, teaching method, curricula content, educational process planning, standard-oriented reform.

\section{INTRODUCTION}

Today higher pedagogical education in Canada is provided only at universities. Therefore, being acquainted with functioning of educational process at modern Canadian universities contributes to a deeper understanding of multilevel teacher education in this country (Карпинська, 2005). Multilevel system of higher education at Canadian universities is not only operated as education and training, but also as research centers. In this regard, Canadian universities are quite popular among students from different countries.

\section{THE AIM OF THE STUDY}

The aim of the study is to analyze the peculiarities of future teachers' content training in the system of multilevel teacher education in Canada.

\section{THEORETICAL FRAMEWORK AND RESEARCH METHODS}

The theoretical basis of the research consists in scientific works of domestic and foreign researchers on the issue of teacher education and multi-encyclopedic sources as 
well as data of Department of Statistics in Canada, legislative acts of provincial departments of education, information documents of Association of Canadian Universities and Colleges (Document d'information de l'AUCC, 2008).

The methods of the study include generalization of existing scientific approaches to defining key concepts of the problem; analysis, synthesis and comparison of multi-level teacher education peculiarities in Canada.

\section{RESULTS}

A characteristic trend of Canadian multilevel teacher education development at the end of the 20th century consisted in governmental elaboration and implementation of standards for skillful teaching based of the theoretical knowledge of the structure, which every teacher should possess. Universities, in their turn, use these standards while developing curricula for different degrees (Bachelor's, Master's and Doctoral).

Thus, structuring content of higher pedagogical education in Canada is aimed at training teachers-professionals and carried out on scientific ground. It is provided by using the achievements of educational philosophy, specifying the substantive merits of pedagogy, revealing peculiarities of educational process at schools, colleges and universities as well as studying subjects from various sectors of education.

Such position can be proved by N. Mukan's research. According to the author, the content of teacher education in Canada (corresponding specialties for different degrees) is defined by industry standards of professional teacher education and higher education in Canada and, based on these characteristics, provides fundamental, psychological, pedagogical, methodical, information-technological, practical, social and humanitarian training of teaching staff (Мукан, 2006).

Today, most Canadian universities engaged in training teaching staff use curricula of two types, namely, concurrent and consecutive (Dennison, 2003). Moreover, the effectiveness of academic programs in teacher education in Canada depends on their educational content and application of education model based on systemic interdisciplinary relations.

While forming the content of future teachers' multilevel training one can observe characteristic increasing of the trend that supposes establishing optimal scientific balance between disciplines of different cycles, theoretical and practical units (modules). Attempts to approximate the content of training programs to the requirements of teaching practice and the trend towards integration of knowledge contributed to the interdisciplinary principle of teachers' training in Canada. This approach is reflected in the general scientific unit (module) of curricula, where the main emphasis is made on humanitarian and social and cultural aspects of higher pedagogical education.

Orientation of Canadian multilevel teacher education at professional development of future teachers is inextricably linked with the principles of differentiation and individualization (personal system instruction) training.

According to these principles, the structure of training courses for teachers' training consists of three main types: 1) academic or independent courses (discrete courses); 2) integrated courses, i.e. interdisciplinary courses; 3) instructional modules (Келли, 2000).

Traditionally, students of pedagogical universities are to master such academic courses as child development; skillful class organization; teaching children with special needs; educational administration; teaching methodology of various subjects studied at secondary schools; learning theory; pedagogic philosophy, etc.

It should be mentioned that the educational process at pedagogical universities as well as other higher education institutions in Canada is regulated individually: students are 
allowed to choose individual curricula based on the selection of the proposed modular professional courses according to their personal professional needs. These offered courses are annually listed in university handbooks (Document d'information de l'AUCC, 2008).

In general, the content of curricula aimed at training future teachers at different degrees in Canada reveals important issues reflecting the current state of education and future prospects of its development and is focused on the methodology of teaching extraordinary, gifted children as well as children with special needs. The curricula also cover problems in multicultural education, teaching at rural and urban schools and other issues that are hardly considered in the process of future teachers' training in Ukraine.

Professional training of future specialists in higher education requires the use of effective innovative forms and methods of pedagogical activity and Canadian experience can be of assistance in this matter as the development of multilevel teacher education in this country has determinated the creation of updated teaching methods (Видишко, 2007).

The key point that should be taken into account while choosing teaching methods is the need to ensure students' learning motivation, that is to consider their psychological peculiarities.

Prevailing among traditional teaching methods in Canadian experience are:

1. Methods of training for practice (monitoring specialists' activities, analysis of real and modeled situations, different types of modeling, practice).

2. Methods of creative thinking development (independent transfer of knowledge and skills into a new training situation; the ability to see new problems; acquaintance with the structure of the object under study; adoption of alternative solutions; ability to combine one's own solutions while creating new and updated teaching ways).

Let us consider the specific application of these methods in higher education institutions of Canada.

1. Methods of training for practice:

Observation is often used in combination with a system of methods related to TV and as a component of a more complex method of "learning episodes".

Analysis of real and modeled situations involves using the method of "learning episodes" and method of "protocols".

The method of "learning episodes" consists of the following elements: a theoretical introduction, observing teacher's activities in the classroom, using the method of self-teaching, analysis of teacher's and student's activity.

The method of "protocols" (followed by recording or describing pedagogically important event) can prepare future teachers under the guidance of a supervisor for critical situations before facing them in practice.

Modeling of certain learning situations presupposes practical lessons to be followed by displaying situations recorded on the tape. Students are encouraged to demonstrate their own solutions to them. Teachers analyze the students' responses that, to some extent, predicts the audience behavior. Then final episodes of the movie which are compared with ways students chose to solve given problems are demonstrated. The purpose of this practical lesson is to determine the optimal behavior of future teachers.

Such methods as role and business games are also commonly used. One of the most common types of role play is a method of micro study. With its help future teachers acquire some teaching techniques skills, in particular, facial expressions, control over their emotions, attention, observation, speaking techniques as well as different didactic, organizational and communicative skills. 
In Canada practice in educational process plays a crucial role in training future teachers to apply acquired abilities and skills in professional activity. One of the most common forms in practice organization used at Canadian pedagogical universities and considered as the most effective in terms of approximating study to practical problems in future activities is the so-called "cooperative learning" (Видишко, 2007). Such training is carried out through alternating theoretical training with practice at school within the chosen specialty.

2. Methods of creative thinking development:

The main objective of methods of creative thinking development mainly consists in eliminating psychological barriers that prevent the generation of ideas, namely, creation of the conditions stipulating for demonstration of students' natural creative abilities in normal study or work environment or application of these methods in practical activities.

Projects, term papers and dissertations contribute to creative thinking development. Project is a real prediction (recommendation) of what should be done in terms of future career. Term paper develops students' skills of information systematization on a particular issue. Thesis suggests students' independent research under the guidance of a scientific supervisor. Scientific and pedagogical work in Canada is recognized as an important means of improving the creative potential of students (future teachers).

Change of conditions and requirements to teachers' activities in the context of the transformation of economic, demographic, social, cultural and educational determinants of the late 20th century has led to the development of reforms in the education system. As we have already noted, departments and provincial ministries of education are responsible for the development of content standards of teacher education in Canada. The abovementioned standards in the provinces of Alberta, British Columbia and Quebec are considered to be the most specific with requirements to expected outcomes included.

According to experts in Canadian educational policy (Robson, Hepburn, 2002) the standards assist in facilitating the planning of the educational process in the teachers' training.

Canada's greatest achievement in teacher education was the creation of Teacher Performance Appraisal Manual and Approved Forms and Guidelines (Ontario Ministry of Education, 2002). Since the end of the 20th century they are the foundation for curricula of Bachelor and Master degrees in Education.

\section{CONCLUSIONS}

So, it has been proved that throughout the whole history of forming multilevel teacher education social and historical conditions of pedagogical work development in Canada were powerful factors in its movement towards full-fledged profession. Rapid social changes at the end of 19th - at the beginning of 21st centuries led to new demands and duties of teachers set out in standards of their professional evaluation. It has been determined that the development of teacher education in Canada in terms of multilevelness is focused on training specialists competitive in the labour market. In the 20th century Canada needed a teacher who is able to respond quickly and flexibly to changes in the structure of education and public life. Canadian system of teacher education at the beginning of the 20th century faced the urgent task of implementing innovative educational changes caused by transformations in society.

Prospects for further research in the field of multilevel teacher education are seen in examining innovative educational forms and methods of training at every educational level. 


\section{REFERENCES}

1. Dennison, J. (2003) The Canadian Encyclopedia. Historica Foundation of Canada. Retrieved 12.12.2015 from : http://www.thecanadianencyclopedia.com/index. $\mathrm{cfm} ? \mathrm{PgNm}=\mathrm{TCE} \& \mathrm{Params}=\mathrm{A} 1 \mathrm{ARTA} 0010058$.

2. Document d'information de l'AUCC. (2008). Les repercussions du Processus de Bologne pour les universités canadiennes. Retrieved 23.11.2015 from : http://www.aucc.ca.

3. Hepburn, C. (2001). Can the Market Save Our Soul? Vancouver BC (Canada) : The Fraser Institute, $325 \mathrm{p}$.

4. Ontario Ministry of Education. (2002). Teacher Performance Appraisal Manual and Approved Forms and Guidelines. Toronto : Queen's Printer for Ontario, $77 \mathrm{p}$.

5. Robson, W., Hepburn, R. (2002). Learning from Success: What Americans Can Learn from School Choice in Canada. Indianapolis, Vancouver : Milton \& Rose Friedman Foundation and The Fraser Institute, $46 \mathrm{p}$.

6. Видишко, Н. В. (2007). Педагогічна зорієнтованість вищої освіти в Канаді [Pedagogic Orientation of Higher Education in Canada]. Наукові записки [Scientific Notes], No 21, pp. 307-310 (in Ukrainian).

7. Келли Дж., Данко, Р., Корзинский, Е. (2000). Образование в Канаде : современное состояние и тенденции развития [Education in Canada : Modern State and Trends in Development]. Педагогика [Pedagogy], No 1, pp. 93-100 (in Russian).

8. Карпинська, Л. О. (2005). Формування професійної майстерності майбутніх учителів у системі вищої педагогічної освіти Канади [Forming of Future Teachers' Professionalism in Higher Education System of Canada]. Thesis for PhD in Pedagogical Sciences. Південноукраїнський державний педагогічний університет імені К. Д. Ушинського, 194 p. (in Ukrainian).

9. Мукан, Н. В. (2006). Система професійної підготовки майбутніх учителів загальноосвітніх шкіл в університетах Канади [System of Professional Training of Future Secondary School Teachers at Canadian Universities]. Л. : НУ “Львівська політехніка", 140 p. (in Ukrainian). 